\title{
Performance of Holstein Cows Grazing on Intensively Managed Tropical Grass Pastures at Three Stocking Rates ${ }^{1}$
}

\author{
M. Antoni-Padilla, J. Fernández-Van Cleve, J. A. Arroyo-Aguilú and \\ R. Quiñones-Torres ${ }^{2}$
}

\begin{abstract}
In a grazing experiment at the Gurabo Agricultural Experiment Substation we measured the performance of Holstein cows at stocking rates of 2.5, 5.0, and 7.5 cows per ha. All cows received concentrate feed at the rate of $1.0 \mathrm{~kg}$ per $2.0 \mathrm{~kg}$ of milk from the first to the 180 th day of lactation and of $1.0 \mathrm{~kg}$ per $4.0 \mathrm{~kg}$ of milk thereafter. Results suggest that when a relatively high concentrate supplementation is given, well-fertilized tropical pastures may sustain grazing cows at the stocking rate of 5.0 cows per ha, as economically and safely as at the stocking rate of 2.5 cows/ha. The stocking rate of 5.0 cows per ha may be recommended for those regions where land and land maintenance costs are high.
\end{abstract}

\section{INTRODUCTION}

Milk production is the most important segment of the agricultural economy of Puerto Rico. The gross farm income generated by this sector in 1980-81. was $\$ 158$ million (13), $27 \%$ of the total gross farm income of Puerto Rico for that year. No single sector made a higher contribution.

A study conducted in 1980 by Choudhury (4) on 120 dairy farms, revealed that the mean concentrate feed intake was $2,415 \mathrm{~kg}$ per cow. With a mean milk yield of $3,767 \mathrm{~kg}$ per cow, the concentrate feed was consumed at a rate of $0.64 \mathrm{~kg}$ per $\mathrm{kg}$ of milk. It was pointed out by CaroCostas and Vicente-Chandler (2) that the concentrate intake per unit of milk produced is higher in Puerto Rico than in the United States, where feed costs are lower. Concentrate costs being the major factor of milk production costs (12), an efficient utilization of this input is of great importance.

Intensively managed pastures are an important feed resource to dairymen in the tropics. Caro-Costas and Vicente-Chandler (3) determined that the feeding of commercial feeds can be sharply reduced by the use of well-fertilized pastures. In a later study (2), they found that cows fed only on well-managed tropical grass pastures with no concentrate feeds can produce fairly high yields.

From experiments conducted in both tropical and temperate areas,

${ }^{1}$ Manuscript submitted to Editorial Board August 17, 1982.

${ }^{2}$ Assistant Economist, Agricultural Economics and Rural Sociology Department; Research Assistant, Nutritionist, and Former Research Assistant, Animal Industry Department, Agricultural Experiment Station, Mayagüez Campus, University of Puerto Rico, Rio Piedras, P.R. 
there is a general agreement that a low level of supplementary feeding (1.4 to $2.3 \mathrm{~kg}$ per day) is insufficient to produce a relatively high milk yield $(5,8,9,15)$. However, supplementation at a ratio of $1 \mathrm{~kg}$ of concentrate to 1,2 , or $3 \mathrm{~kg}$ of milk increased yields significantly $(6,7$, 14). The conclusion from most of these experiments was that the supplement cost exceeds the value of the additional milk produced.

The present study is part of a series of experiments to evaluate feeding systems in dairy cattle. The objective of this study was to determine the feeding system that is best suited for the most efficient use of tropical grasses and of concentrate feeds for more economical milk production.

McDowell et al. $(10,11)$ showed that medium, but not high, levels of supplementary feeding were economically feasible for lactating cows grazing on high quality tropical grass pastures at a stocking rate of 2.5 cows per ha. Later, Yazman et al. (16) studied stocking rates of 2.5 cows per ha and various concentrate feed levels, and of 5.0 cows per ha and a high concentrate feed. level. They stated that for the most efficient use of pastures and concentrate where land costs are high, the ideal grazing rate is 5.0 head per ha supplemented with concentrate at the rate of 1.0 $\mathrm{kg}$ per $2.0 \mathrm{~kg}$ of milk.

The positive results reported by Yazman et al. (16), with a stocking rate of 5.0 cows per ha, and the potential benefit of these findings to the dairyman, who faces higher land and land maintenance costs, led to the present experiment, in which three stocking rates with a uniform supplementation level were evaluated.

\section{MATERIALS AND METHODS}

The experiment was conducted at the Gurabo Agricultural Substation from January, 1978 to June, 1981. Details such as location, temperature range, and rainfall are given in the reports on former experiments performed at this Station $(9,11)$. Three different stocking rates were evaluated with the following treatments:

T1 - cows grazing at the stocking rate of 2.5 per ha plus $1.0 \mathrm{~kg}$ of commercial concentrate feed, $20 \%$ crude protein (CP), per 2.0 $\mathrm{kg}$ of milk from the first to the 180th day of lactation, and of 1.0 $\mathrm{kg}$ per $4.0 \mathrm{~kg}$ of milk thereafter.

T2 - cows grazing at the stocking rate of 5.0 per ha plus concentrate feed as in T1.

T3 - cows grazing at the stocking rate of 7.5 per ha plus concentrate feed as in T1.

Animals were distributed at random among the treatments, stratified as to milk yield and lactation stage. A total of 135 cows were distributed as follows: 45 cows on 180 ha (T1), 51 cows on 6.4 ha (T2), and 39 cows on 5.2 ha (T3). Three different pasture areas were assigned to each of 
the treatments. Pasture area of each treatment was divided into four paddocks, on which the animals were grazed for 7 days on a rotational schedule. The paddocks consisted entirely of grasses, mainly Pangola (Digitaria decumbens Stent), intermixed with Star (Cynodon nlemfuensis var. nlemfuensis), Guinea (Panicum maximum Jacq.), Para (Brachiaria purpurascens (Raddi) Henr.), and some native species. All pastures were fertilized with 2,240 $\mathrm{kg}$ of a 15-5-10 analysis per ha per yr in four equal applications.

Within the experiment, some cows completed two whole consecutive lactations. However, most of them completed only one. The study included only those cows which started on the experiment shortly after freshening, with no more than 20 days of pre-treatment yield, and which completed their lactations within their respective treatment, with no more than 40 days of post-treatment yield. The cows not completing these requirements were treated as non-test cows needed to maintain the proper stocking rate. This was designed to avoid any significant bias to the data due to production outside the experiment. The lactation period ended when the daily yield declined to less than $4.5 \mathrm{~kg}$ per day, or when calving was expected within 2 mo. Only cows with known calving date after completion of the experiment were considered for calving length calculations on all cows and yield per cow per yr extensions.

Statistical analyses were not performed because the various treatments were assigned to different areas, even though the areas were not far from each other and had similar pasture conditions. In particular, the area assigned to T3 was much closer to the milking parlor (about $100 \mathrm{~m}$ ) than the areas assigned to $\mathrm{T} 1$ and $\mathrm{T} 2$ (about $1 \mathrm{~km}$ ). Cows on $\mathrm{T} 3$ walked considerably less for milking.

\section{RESULTS AND DISCUSSION}

Table 1 shows the means and standard errors of the means for selected measures of performance by stocking rates. Milk yield per lactation was higher for T1, with a mean yield of $4,287 \mathrm{~kg}$ per cow, followed closely by T2 and T3, with mean yields of 4,197 and 4,115 kg per cow, respectively. On the other hand, the calving interval for T1 was higher, with 466 days between calvings. The calving interval for T2 was the lowest: 421 days. T3 had a calving interval of 445 days. When the mean milk yield per cow per year was calculated, the higher calving interval for T1 turned against the treatment, and its milk yield for this measurement was the lowest, with 3,491 kg per cow per year. Milk yields for T2 and T3 were 3,727 and $3,511 \mathrm{~kg}$ per cow per year, respectively.

The fairly good performance of T3 as compared with that of T1 was interesting. Further analyses were carried out to identify the probable causes of this behavior. Table 2 presents CP contents in samples collected 
TABLE 1.-Means and standard errors of the means for selected measures of performance by stocking rates

\begin{tabular}{|c|c|c|c|c|}
\hline \multirow{2}{*}{ Description } & \multirow{2}{*}{ Unit } & \multicolumn{3}{|c|}{ Stocking rates (cows per ha) } \\
\hline & & 2.5 & 5.0 & 7.5 \\
\hline Cows & No. & 46 & 48 & 34 \\
\hline Milk production per lactation & $\mathrm{kg}$ & $4287 \pm 117$ & $4197 \pm 169$ & $4115 \pm 151$ \\
\hline $\begin{array}{l}\text { Concentrate consumption per } \\
\text { lactation }\end{array}$ & $\mathrm{kg}$ & $1950 \pm 50$ & $1929 \pm 69$ & $1898 \pm 60$ \\
\hline Calving interval & days & $466 \pm 16$ & $421 \pm 12$ & $445 \pm 22$ \\
\hline Milk production per cow-year & $\mathrm{kg}$ & $3491 \pm 128$ & $3727 \pm 166$ & $3511 \pm 143$ \\
\hline $\begin{array}{l}\text { Concentrate consumption per } \\
\text { cow-year }\end{array}$ & $\mathrm{kg}$ & $1594 \pm 60$ & $1718 \pm 71$ & $1631 \pm 67$ \\
\hline Initial body weight $^{1}$ & $\mathrm{~kg}$ & $509 \pm 12$ & $531 \pm 10$ & $539 \pm 11$ \\
\hline Final body weight ${ }^{2}$ & $\mathrm{~kg}$ & $485 \pm 9$ & $495 \pm 7$ & $523 \pm 12$ \\
\hline Change in body weight & $\mathrm{kg}$ & 24 & 36 & 16 \\
\hline Milk production - up to 304 days & $\mathrm{kg}$ & $4189 \pm 112$ & $4164 \pm 164$ & $4000 \pm 137$ \\
\hline $\begin{array}{l}\text { Concentrate consumption up to } \\
304 \text { days }\end{array}$ & $\mathrm{kg}$ & $1919 \pm 50$ & $1919 \pm 68$ & $1867 \pm 58$ \\
\hline Milk yield, mature equivalent ${ }^{3}$ & $\mathrm{~kg}$ & $4468 \pm 111$ & $4388 \pm 161$ & $4185 \pm 149$ \\
\hline
\end{tabular}

${ }^{1}$ Initial weight taken within the first 30 days of lactation.

${ }^{2}$ Final weight taken within the last 30 days of lactation.

${ }^{3}$ Age and month of calving adjustment performed with correction factors derived for Holstein cows in Puerto Rico (1).

TABLE 2.-Percentage of crude protein in pasture samples collected in 1978 before and after grazing, by stocking rates

\begin{tabular}{lccc}
\hline & Date & \multicolumn{3}{c}{ Stocking rates (cows per ha) } \\
\cline { 2 - 4 } & 2.5 & 5.0 & 7.5 \\
\hline & & Before grazing & \\
April & 14.46 & 13.54 & 17.88 \\
June & 14.34 & 12.25 & 15.44 \\
August & 15.69 & 15.19 & 17.10 \\
September & 19.35 & 18.91 & 21.10 \\
November & 18.07 & 17.75 & 18.78 \\
$\quad$ Mean & 16.38 & 15.53 & 18.06 \\
& & After grazing & \\
April & 11.50 & 11.59 & 9.29 \\
June & 10.66 & 9.66 & 9.85 \\
August & 13.13 & 8.85 & 9.63 \\
September & 13.60 & 12.10 & 10.57 \\
November & 12.82 & 11.07 & 8.10 \\
$\quad$ Mean & 12.34 & 10.65 & 9.49 \\
\hline
\end{tabular}

before and after grazing. The before-grazing CP content on T3 samples was the highest in all the samples taken in various months; thus, pasture regrowth was more effective in the larger stocking rates. In T1 and T2 samples, there was probably a larger fibrous residue, which interfered 
with the 21-day recovery phase of the pastures. The after-grazing CP content on T3 pastures was the lowest, probably because of the more intensive grazing of the pastures.

Cows that did not complete full lactations within the experiment or had calving intervals missing because of sale or death before the next calving date were eliminated. The main reason for the sale was that the cows were considered non-breeders because of reproduction problems, produced abnormally low yields, or had serious health problems.

The extent to which the withdrawal of some cows could have benefitted $\mathrm{T} 3$ as against $\mathrm{T} 1$ or $\mathrm{T} 2$ is not clear. Table 3 presents the number of cows, by stocking rate, withdrawn from the study for various reasons.

A total of 12 cows were withdrawn from T3, compared with 7 and 9 for $\mathrm{T} 1$ and $\mathrm{T} 2$, respectively. Of the 12 cows in T3, three were eliminated because of death or other reasons not attributable to treatment effects. The corresponding quantities for T1 and T2 were 3 and 5, respectively.

TABLE 3.-Cows withdrawn from the study for various reasons by stocking rates

\begin{tabular}{lrrr}
\hline \multirow{2}{*}{ Reason for withdrawal } & \multicolumn{3}{c}{$\begin{array}{c}\text { Stocking rates (cows } \\
\text { per ha) }\end{array}$} \\
\cline { 2 - 4 } & 2.5 & 5.0 & 7.5 \\
\hline Died for reasons not attributable to treatment effects & 2 & - & 2 \\
Calving interval missing & 4 & 4 & 9 \\
Other reasons & 1 & 5 & 1 \\
$\quad$ Totals & 7 & 9 & 12 \\
\hline
\end{tabular}

No complete lactation records were available for these cows. Nine cows were withdrawn from T3 because of missing calving intervals as compared with 4 for both T1 and T2. This could have benefited T3 to the extent that, if it could have been taken, the possible higher calving interval of these cows could have probably lowered the mean yield per cow per year of the treatments. On the other hand, the mean yield per lactation for these cows was 2,554 $\mathrm{kg}$ for T1, 4,611 $\mathrm{kg}$ for T2, and 3,079 $\mathrm{kg}$ for T3. Both treatments T1 and T3 probably slightly benefited from the withdrawal. It remains unclear whether $\mathrm{T} 2$, with a larger yield per lactation for the withdrawn cows as compared to that of the included cows $(3,727$ $\mathrm{kg}$ ), could have been downward. If it happened, it was only slightly, for only four cows were not included for this reason.

Table 1 also presents the mean milk yield per cow from the beginning up to the 304th day of lactation, or until yield declined to less than 4.5 kg per day. It also presents a correction performed on this yield; the mature-equivalent (ME) milk yield. The ME yield is the milk yield corrected for calving month and age effects, based on corrections factors derived for Holstein cows in Puerto Rico (1). On the basis of these two 
figures, and to the extent that these factors actually corrected the data, it is seen that age and month of calving distribution were favorable to T3. Only $185 \mathrm{~kg}$ were added to the actual mean milk yield of T3 to convert it to ME basis, as compared with T1 and T2, where 279 and 224 $\mathrm{kg}$, respectively, had to be added.

On T3, the lower after-grazing CP content of the pastures and the lower milk yield per lactation probably meant that, although the pastures at the beginning of the grazing cycle were of higher quality, there was not enough pasture to fulfill the cow requirements. In regard to the extent that this condition affected the cows, bodyweight measurements were

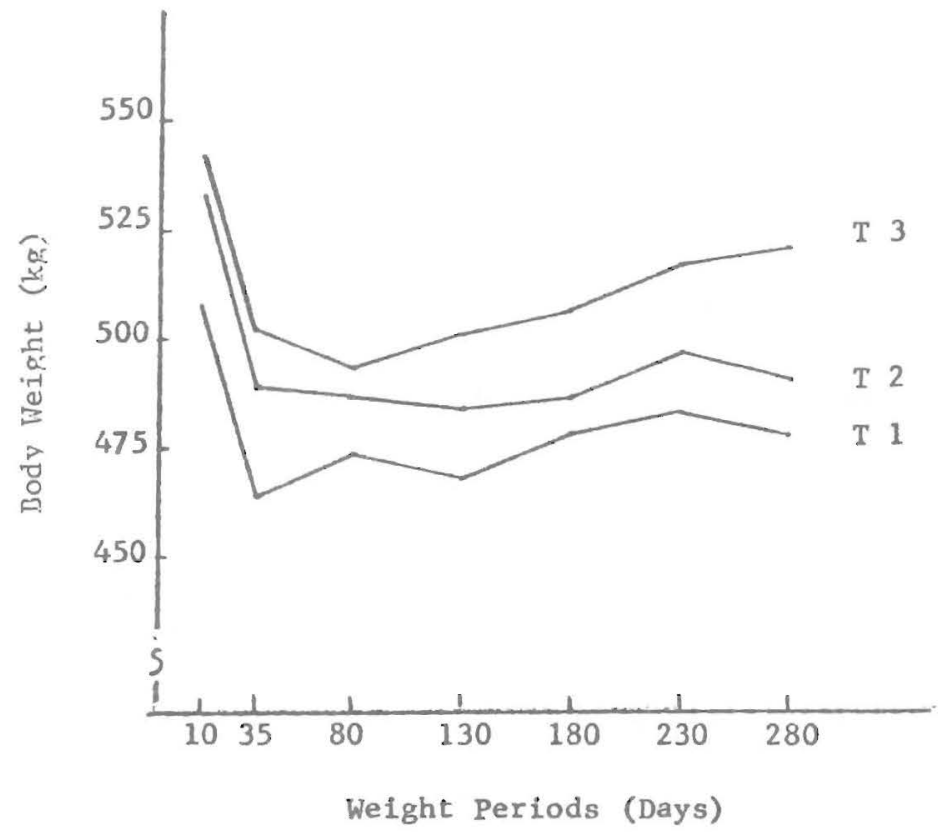

FIG. 1.-Average body weight of cows from the initial weight to the 300th day of lactation.

taken. Table 1 presents initial and final cow weights. The higher stocking rates did not adversely affect cow weight; suggesting that the cows under this condition did not suffer a significant stress. T3 cows, on the average, lost less weight than cows on T1 and T2. To further analize this, figure 1 presents bodyweight changes with lactation time increase. For the construction of this figure, both experimental cows and cows withdrawn for the reasons previously explained, were included. Figure 1 shows that T3 cows recovered as well or better than cows on T1 or T2.

It was observed that $\mathrm{T} 3$ tended to overutilize the pastures, affecting 
the grass stand and eliminating the improved species. Although bodyweight measurements did not demonstrate that this condition affected the cows adversely through the experimental period, it might be speculated that the continuous deterioration of the pastures because of high grazing pressure would eventually decrease the performance of the animals and their health.

\section{ECONOMIC ANALYSIS}

The economic analysis which follows is based on milk price levels, concentrate feeds, and fertilizers prevailing in Puerto Rico in January 1982. This is a partial economic analysis to compare the three stocking rates for those factors that influenced them in unequal ways. For the individual dairyman interested in the expected performance of the treatments on his farm, the best way to analyze the data from an economic point of view is to substitute the price and labor estimates given here by those that prevail on his particular farm. The interest on investment in land can also be replaced by the actual cost of his factor or by the land rent for those who rent the land.

Table 4 shows the expected economic returns per cow per year over some of the production factors, by stocking rates. On the basis of a milk price of $\$ 0.483$ per $\mathrm{kg}$, the gross income per cow per year averaged $\$ 1,688$, $\$ 1,802$, and $\$ 1,697$ for cows in $\mathrm{T} 1, \mathrm{~T} 2$, and $\mathrm{T} 3$, respectively. When concentrate feed cost $(\$ 0.281$ per $\mathrm{kg})$ was deducted from this income, the expected return over the concentrate cost was higher for $\mathrm{T} 2$, with a return of $\$ 1,320$, followed by $\mathrm{T} 1$ and $\mathrm{T} 3$, with returns of $\$ 1,241$ and $\$ 1,239$, respectively. When the cost of fertilizer ( $\$ 0.2513$ per $\mathrm{kg}$ ) was deducted, the higher amount of fertilizer per cow per year utilized in T1 reduced more the expected income over the fertilizer costs for this treatment than for T2 and T3. The expected income for T2 was the highest, with $\$ 1,206$ followed closely by T3 with $\$ 1,163$. The expected income for $\mathrm{T} 1$ was the lowest, with $\$ 1,013$. When the interest on land investment was deducted (based on a land price of $\$ 2,470$ per ha and an interest rate of $8 \%$ ), the income over the cost of concentrate, fertilizer, and interest over land were $\$ 933, \$ 1,166$, and $\$ 1,136$ for $\mathrm{T} 1$, T2, and T3, respectively. The only remaining major operating cost that affected the treatments in unequal ways was the cost of labor used in fertilization, fence repairs, and land maintenance. For this study, an estimate of $\$ 325$ per ha was established. When this deduction was performed on a per cow per year basis, the incomes over the cost of concentrate, fertilizer, interest on land investment, and labor for land maintenance were $\$ 803, \$ 1,101$, and $\$ 1,093$ per cow per year for $\mathrm{T} 1, \mathrm{~T} 2$, and $\mathrm{T} 3$, respectively.

The expected return over all of the selected costs was almost equal for 
TABLE 4.-Economic returns per cow-year for cows grazing at three stocking rates

\begin{tabular}{|c|c|c|c|c|c|c|c|c|}
\hline \multirow{3}{*}{ Description } & \multirow{3}{*}{ Unit } & \multirow{3}{*}{ Price } & \multicolumn{6}{|c|}{ Stocking rates-cows per ha } \\
\hline & & & \multicolumn{2}{|c|}{2.5} & \multicolumn{2}{|c|}{5.0} & \multicolumn{2}{|c|}{7.5} \\
\hline & & & Amount & Value & Amount & Value & Amount & Value \\
\hline & & $\$$ & & $\$$ & & $\$$ & & $\$$ \\
\hline Milk per cow-year & $\mathrm{kg}$ & .48346 & 3491 & 1688 & 3727 & 1802 & 3511 & 1697 \\
\hline Concentrate feed per cow-year & $\mathrm{kg}$ & .2806 & 1594 & 447 & 1718 & 482 & 1631 & 458 \\
\hline Income over the cost of concentrate feed & dol & - & - & 1241 & - & 1320 & - & 1239 \\
\hline Fertilizer & $\mathrm{kg}$ & .2513 & 907 & 228 & 454 & 114 & 302 & 76 \\
\hline Income over the cost of concentrate and fertilizer & dol & - & - & 1013 & - & 1206 & - & 1163 \\
\hline Interest and land investment ${ }^{1}$ & dol & - & - & 80 & 一 & 40 & - & 27 \\
\hline Income over the cost of concentrate, fertilizer and interest & & & & & & & & \\
\hline $\begin{array}{l}\text { on investment in land } \\
\text { Labor }{ }^{2} \text { (fertilizing, weeding, fence repairs, etc.) }\end{array}$ & $\begin{array}{l}\text { dol } \\
\text { dol }\end{array}$ & $\begin{array}{l}- \\
-\end{array}$ & - & $\begin{array}{l}933 \\
130\end{array}$ & 一 & $\begin{array}{r}1166 \\
65\end{array}$ & $\begin{array}{l}- \\
-\end{array}$ & $\begin{array}{r}1136 \\
43\end{array}$ \\
\hline $\begin{array}{l}\text { Income over the cost of concentrate, fertilizer, interest on } \\
\text { land investment and labor for land maintenance }\end{array}$ & dol & - & - & 803 & 一 & 1101 & - & 1093 \\
\hline
\end{tabular}

${ }^{1}$ Land priced at $\$ 2,470$ per ha at $8 \%$ interest.

${ }^{2}$ Estimate. 
T2 and T3, with $\$ 1,101$ and $\$ 1,093$, respectively. They both exceeded almost $\$ 300$ per cow per year the expected return of $\$ 803$ for T1.

It is emphasized that the cost and returns vary with different situations and the figures shown here should serve only as a guide. The returns offered here are only for selected factors. The returns over a given set of factors are amounts that remain to cover for any other expenses necessary for farm operation and profit.

\section{CONCLUSIONS}

The results of this study suggest that well-fertilized tropical pastures may sustain up to five cows per ha, when a relatively high concentrate supplement is given, as economically and safely as with two cows per ha. That T3 cows could have a good performance, as compared to T1 or T2, gives substantial support to this conclusion. In line with this finding and in agreement with the recommendations of Yazman et al. (16), T2 may be recommended for those regions, where land and land maintenance costs are high.

The higher maturity and lower digestibility of pastures observed in T1 indicate that the dairyman in Puerto Rico, generally grazing cattle at this stocking rate and with a higher supplementation level than the one used here, should not increase his present pasture fertilization without withdrawing at the same time some of the feed supplement. A higher fertilization without an adjustment in the supplement level would probably result in lower milk yield than expected, because of pasture overgrowth. With their present level of supplementation, or even with a lower one as the one tested here, the dairymen in Puerto Rico may safely graze up to 5.0 cows per ha, increasing their fertilization level, and improving their pasture quality, if needed.

The better performance of grazing cows in T2 as compared with the performance of cows in T1 does not mean that the higher stocking rate is better than the lower one under all conditions. The feed supplementation level used here is a relatively high one, intended to be used by cows grazing at the rate of 5.0 per ha. Previous experiments of this series $(10,11)$ showed that medium supplementary feedings are indicated for cows grazing in T1. The higher supplementation level used here is due to the need to set a uniform supplementation level for all treatments under comparison, so that pasture utilization could be studied on a uniform basis, with emphasis given to T2. As regards comparisons between cows grazing at the rates of 2.5 and 5.0 cows per ha, with the lower supplementation level recommended by the University of Puerto Rico Agricultural Experiment Station, reference should be made to the study perfrmed by Yazman et al. (16). Updating the economic analysis performed therein is recommended. 
More studies should be conducted on the higher stocking rate $(7.5$ cows per ha) before any attempt is made to utilize it. Its major drawback is the excessive pasture utilization that may possibly and eventually destroy the grass stand.

\section{RESUMEN}

Un experimento en intensidad de pastoreo en el cual se evaluaron las producciones de vacas Holstein pastando a razón de 2.5 (T1), 5.0 (T2) y 7.5 (T3) vacas por ha fue realizado en la Subestación Experimental Agrícola de Gurabo. Todas las vacas recibieron alimento concentrado a razón de $1.0 \mathrm{~kg}$ por cada $2.0 \mathrm{~kg}$ de leche producida durante los primeros 180 días de lactancia y $1.0 \mathrm{~kg}$ por cada $4.0 \mathrm{~kg}$ de leche producida de los 180 días en adelante.

Las producciones medias por vaca y año fueron de 3,491, 3,727 y 3,511 kg para T1, T2 y T3, respectivamente. El beneficio esperado por vaca y año en ingresos sobre el costo del alimento, abono, intereses sobre la inversión en tierras y mano de obra utilizada en el cuido de los pastos fue mayor en T2 y T3.

Los resultados indican que los pastos tropicales cultivados intensivamente pueden sostener animales pastando a razón de 5.0 animales por ha cuando se suministra alimento concentrado en cantidades relativamente altas. También, que la adopción de esta práctica es igualmente factible, tanto desde el punto de vista económico como el nutricional, en comparación con la producción de leche a base de una intensidad de pastoreo de 2.5 animales por ha. La intensidad de apacentamiento de 5.0 animales por ha es recomendable para zonas donde el costo de la tierra y el cuido de los pastos sean altos.

\section{LITERATURE CITED}

I. Camoens, J. K., R. E. McDowell, L. D. Van Vleck, M. Drosdoff, P. O. Miller, G. R. Ufford, J. D. Rivera-Anaya, 1976. Factores para ajustar los registros de producción de vacas Holstein en Puerto Rico, según la edad del animal y el mes de nacimiento, Publ. 99, Esta. Exp. Agríc. Univ. P.R.

2. Caro-Costas, R. and J. Vicente-Chandler, 1980. Feeding Holstein cows exclusively on well managed tropical grass pastures, J. Agric. Univ. P.R. 64 (1): 47-53.

3. - - and-_, 1969. Milk production with all grass rations from steep, intensively managed tropical pastures, J. Agric. Univ. P.R. 53 (4): 251-8.

4. Choudhury, P., 1981. Estudio económico exhaustivo de la Industria Lechera, Appl. Soc. Res., San Juan, P. R.

5. Dirven, J. G. P., 1965. Milk production on grassland in Surinam, Proc. 2 Inter. Grassland Congr., 269 (Abstr.).

6. Donker, J. D., G. C. Marten, and W. R. Wedin, 1968. Effect of concentrate level on milk production of cattle grazing high-quality pasture, J. Dairy Sci. 51: 67-73.

7. Dowden, D. R. and D. M. Seath, 1957. Grain feeding on pasture does not pay, J. Dairy Sci. 40: 613 (Abstr.). 
8. Hamilton, R. I., L. J. Lambourne, R. Roe, and D. J. Minson, 1970. Quality of tropical grasses for milk production, Proc. XI Inter. Grassland Congr., 860-4.

9. Jeffery, H. J., R. L. Coleman, A. B. Dale, and J. M. Holder, 1970. Milk production from unimproved and improved grazing system with and without a grain supplement, Proc. Austr. Soc. Anim. Prod. 8: 476-81.

10. McDowell, R. E., H. Cestero, J. D. Rivera-Anaya, F. Román-Grarcía, J. A. ArroyoAguilú, C. M. Berrocal, M. Soldevila, J. C. López-Alberty, and S. W. Metz, 1975. Tropical grass pastures with and without supplement for lactating cows in Puerto Rico, Agric. Exp. Stn. Univ. P. R. Bull. 238.

11. _-, - - - - M. Soldevila, F. Román-Garciá and J. A. Arroyo-Aguilú, 1977. Value of supplementary feeding for lactating cows grazing fertilized grass pastures in Puerto Rico, J. Agric. Univ. P. R. 61 (2): 204-16.

12. Puerto Rico, 1980. Oficina de Estudios Económicos, Departamento de Agricultura, Actualización del estudio económico de la Industria Lechera de 1976-77 al año 197980. San Juan, P. R.

13. Puerto Rico. 1980. Junta de Planificación. Informe económico al Gobernador, San Juan, P.R.

14. Thurbon, P. N., G. A. Chambers, R. Sibbick, and J. Stohoe, 1973. Progress report on milk production from cows grazing irrigated, fertilized Digitaria decumbens as influenced by stocking rate and molasses/biuret supplement, Proc. 3 World Conf. Anim. Prod. 1:2(b)-12-2(b)-14.

15. Vicente-Chandler, J., F. Abruña, R. Caro-Costas, J. Figarella, S. Silva and R. W. Pearson, 1974. Intensive grassland management in the humid tropics of Puerto Rico, Agric. Exp. Stn. Univ. P. R., Bull. 233.

16. Yazman, J. A., R. E. McDowell, H. Cestero, F. Román-Garcia and J. A. Arroyo-Aguilú, 1979. Supplementation of dairy cows grazing intensively managed tropical grass pastures at two stocking rates, J. Agric. Univ. P. R. 63 (3): 281-93. 